Hypothesis

\title{
Related Party Transactions and Tax Avoidance of Business Groups
}

\section{Sungwon Park}

School of Business, Hanyang University, 222 Wangsimni-ro, Seongdong-gu, Seoul 04763, Korea; scdjsw@hanyang.ac.kr

Received: 31 July 2018; Accepted: 30 September 2018; Published: 6 October 2018

check for updates

\begin{abstract}
This study aims to examine if the firms in business groups avoid tax by related party transactions. If other conditions are the same, firms have an incentive to maximize after-tax profits by minimizing tax burden. If the firms are in business groups, they tend to minimize tax at the business group level. It is expected that the level of tax avoidance of both parties of related party transactions will be high if tax is minimized at the business group level as the transactions will be made at a level that can minimize the tax of both the firm that reduces the taxable income through related party transactions and the firm whose taxable income increases. In addition, the effect of being in a Chaebol business group and the effect of the Unfair Related Party Transactions Tax Law on the association with related party transactions and tax avoidance are also examined. According to this study, the firms in business groups avoid tax by related party transactions. It is also found out that tax avoidance by related party transactions is done more aggressively in Chaebol member firms than non-Chaebol firms, while tax avoidance by related party transactions in Chaebol business groups decreases after the implementation of the Unfair Related Party Transactions Tax Law.
\end{abstract}

Keywords: related party transactions; tax avoidance; Chaebol; Unfair Related Party Transactions Tax Law

\section{Introduction}

Corporate tax is an important item of cash outflow for firms. If other conditions are the same, firms have an incentive to maximize after-tax profits by minimizing tax burden. If the firms are in business groups, they tend to minimize tax at the business group level (Gramlich et al., 2004 [1], Jung et al., 2009 [2], Lee 2010 [3], Choi et al., 2011 [4], Lee and Yoon 2012 [5]). This study aims to examine if the firms in business groups avoid tax by related party transactions.

Gramlich et al. (2004) [1] and Jung et al. (2009) [2] argued that the firms in business groups minimize tax by income shifting, and Lee (2010) [3] and Lee and Yoon (2012) [5] provided evidence that business groups shift income by related party transactions. Related parties have a substantial influence on the business counterpart, and thus, it is possible to adjust the terms and conditions and amount of transactions as they wish. A firm with much tax burden can reduce the taxable income by doing business with related parties that have a low level of tax burden with favorable terms, and such a decision will be made in the direction to minimize tax at the business group level. It is expected that the level of tax avoidance will be higher if the amount of related party transactions is larger if the strategy of minimizing tax by related party transactions is adopted.

Chaebol is a form of business organization unique to Korea. The Fair Trade Commission defines Chaebol as a business group with over KRW five trillion of total assets of the domestic business group member firms (affiliate firms) in the balance sheet of the prior year. A Chaebol business group has more and larger affiliated companies than a non-Chaebol business group. Jung et al. (2009) [2] argued that the marginal tax rate of a Chaebol is less than that of non-Chaebol firms, which implies that Chaebol 
business groups are applied lower tax rates through income shifting. Chaebol firms have sufficient infrastructure that can be used for their tax strategy, and their corporate governance is well-suit for income shifting. Thus, they can avoid tax more effectively using related party transactions.

It is regulated by Unfair Related Party Transactions Tax Law that a gift tax shall be imposed on the controlling shareholder, etc., of the beneficiary corporation if certain requirements are met for taxation including $30 \%$ or more of the ratio of sales to a related party. As the related party transactions for minimum tax at the business group level will not be done in excess of $30 \%$ of all transactions in order to avoid the gift tax, the Unfair Related Party Transactions Tax Law will be a constraint for the strategy to minimize tax at the business group level. Therefore, it is expected that the Unfair Related Party Transactions Tax Law will affect the tax strategy using related party transactions at Chaebol groups.

This study analyzes the firms that belonged to the business groups listed on the Korea Composite Stock Price Index (KOSPI) market from 2001-2016. The results of the analysis show, first, that the level of tax avoidance is higher when the amount of related party transactions became larger. This suggests that if tax is minimized at the business group level by related party transactions, the level of tax avoidance at the individual firm level is also high. Second, the positive association of the amount of related party transactions and tax avoidance is stronger in Chaebol member firms. It seems that Chaebol member firms avoid tax more easily by related party transactions using a corporate governance well-suited to income shifting, as well as various related parties. Third, the positive association of the amount of related party transactions and tax avoidance is weakened in Chaebol member firms after the implementation of the Unfair Related Party Transactions Tax Law. This suggests that regulation of the percentage of related party transactions by the implementation of the Unfair Related Party Transactions Tax Law works as a constraint on the tax strategy using related party transactions.

The following are the contributions of this study. First, the association of related party transactions and the tax avoidance at the individual firm level is examined. The prior research (Gramlich et al., 2004 [1], Jung et al., 2009 [2], Lee 2010 [3], Lee and Yoon 2012 [5]) has mainly examined income shifting and tax minimization at the business group level. Gramlich et al. (2004) [1] and Jung et al. (2009) [2] examined if business group member firms do income shifting using dummy variable of belonging to a business group as the independent variable. Lee (2010) [3] and Lee and Yoon (2012) [5] examined the effect of the related party transaction amount on income shifting. Such research is different from this study in that they used only the fact of belonging to a business group as the independent variable or used the pre-tax return on assets as the dependent variable. Choi et al. (2011) [4] is similar to this study in that it examined the effect of related party transaction amount on the tax avoidance at the firm level. However, they only used the tax avoidance measure suggested by Desai and Dharmapala (2006) [6] as the tax avoidance measure. As DDBTD is the measure that captures tax shelter, this study added the cash effective tax rate, which can measure the overall tax burden of firms as the tax avoidance measure. The research of Choi et al. (2011) [4] was expanded in consideration of the effect of the fact of belonging to a Chaebol business group and the Unfair Related Party Transactions Tax Law on the relations between related party transactions and tax avoidance. Instead, this study directly examines the effect of the amount of related party transactions on the tax strategy by using the measures of tax avoidance, not pre-tax return on assets, as the dependent variable for the direct examination of the influence of the amount of related party transactions on the tax strategy at the individual firm level. Second, there was a necessity for the expansion of consolidated tax return. Korea introduced the system of consolidated tax return in early 2010. However, the effect of the system is limited, as it can only be adopted by the subsidiaries $100 \%$ wholly owned by their parent companies. According to Kim (2015) [7], only 42 firms have chosen a consolidated tax return from 2010-2014. The consolidated tax return calculates tax amount regarding the parent company and the subsidiaries as a single economic substance. As the consolidated tax return calculates tax amount regarding a business group as a single entity, the firms subject to a consolidated tax return do not have an incentive to shift income using related party transactions. Tax avoidance using related party transactions with firms in the business group with a low tax rate will decrease if the objects of the consolidated tax return 
are expanded. The firm value will probably increase by the reduction in such transactions, as related party transactions for tax avoidance lack economic rationality. Third, this study examines the policy effect of the Unfair Related Party Transactions Tax Law. The Unfair Related Party Transactions Tax Law is being implemented for the prevention of unfair inheritance of wealth by related party transactions. While the Unfair Related Party Transactions Tax Law is enacted for the regulation of avoidance of the gift tax by the owner family, it also has an effect on the activity of tax avoidance by related party transactions. This study shows that the Unfair Related Party Transactions Tax Law has the effect of decreasing tax avoidance of a firm in addition to the effect of preventing unfair inheritance of wealth.

The remainder of this paper is organized as follows: Section 2 reviews the extant literature and provides the research hypotheses. Section 3 describes the research design and the sample selection. Section 4 reports the main empirical results. Finally, Section 5 concludes.

\section{Literature Review and Research Hypotheses}

\subsection{Related Party Transactions and Tax Avoidance}

Firms have the incentive to maximize profits by minimizing corporate tax, which is an important item of cash outflow. Business groups use the strategy to minimize tax at the business group level (Gramlich et al., 2004 [1], Jung et al., 2009 [2], Lee 2010 [3], Choi et al., 2011 [4], Lee and Yoon, 2012 [5]). Prior research on tax minimization at the business group level has been done mainly focusing on income shifting. Harris et al. (1993) [8], Klassen et al. (1993) [9], Jacob (1996) [10], Collins et al. (1998) [11] and Ko (2000) [12] conducted studies on multinational corporations in different jurisdictions and reported their study results that the multinational corporations shift income from a country with higher tax rates to another country with lower tax rates. However, Shackelford and Shevlin (2001) [13] argued that the studies on the income shifting by multinational corporations have measurement errors due to the different criteria for financial reporting between nations. After then, scholars have carried out research on the income shifting in the same jurisdiction. There may be a difference in the level of tax burden of firms even in the same jurisdiction according to the tax strategy, net operating loss, tax credit, etc. Gramlich et al. (2004) [1] and Jung et al. (2009) [2] examined the tax minimization of the firms belonging to business groups. A firm belonging to a business group with much tax burden has a low level of pre-tax return on assets showing that the income is shifted from a firm with a high tax rate in the business group to a firm with a low tax rate. They argued that the firms in business groups minimize tax through income shifting. Lee (2010) [3] and Lee and Yoon (2012) [5] examined the effect of related party transactions on income shifting and suggested that income shifting occurs by the motive of tax minimization by related party transactions. Meanwhile, Jacob (1996) [10] examined if multinational corporations of the U.S. are avoiding tax through transactions with overseas related parties. The results of the analysis show that the burden of corporate tax at the business group level decreases as the portion of related party transactions increases. Such research shows that tax avoidance at the business group level is done by related party transactions.

Related parties have substantial influence on the business counterpart, and thus, it is possible to adjust the terms and conditions and amount of transactions as they wish. K-IFRS (Korean International Financial Reporting Standard) 1024 makes it mandatory to disclose related party transactions. It is stated that related party transactions may affect the net income and financial state of a firm as a product of being sold to the controlling firm at cost price by a firm, which may not be sold to another firm with the same conditions, and the amount of related party transactions may be different from the amount of transaction with the companies that are not related. As a result, related parties may have a substantial influence on the firm and the conditions of operating and financial state. As the footnote of the audit report that discloses related party transactions only shows the name of the related party and amount of transaction and does not disclose specific transaction conditions, there is a possibility that the management may adjust the transaction price to their own advantage (Choi et al., 2011 [4]). A firm with much tax burden can reduce the taxable income by doing business with related parties that have a low level of tax burden with favorable terms, and such a decision will be made in the 
direction to minimize tax at the business group level. Choi et al. (2011) [4] argued that a manager who wants to avoid tax by related party transactions makes a decision in consideration of the tax cost of both firms. That is, related party transactions are done at a level where the reduction of tax burden of firms with a higher tax rate is more than the effect of the increase of the tax burden of the firms with a lower tax rate. The firms with a lower tax rate will do related party transactions at a level where the low tax rate is maintained, and the companies with a higher tax rate will attempt to lower the tax rate by related party transactions. It is expected that the level of tax avoidance of both parties of related party transactions will be high if tax is minimized at the business group level, as the transactions will be made at a level that can minimize the tax of both the firm that reduces the taxable income through related party transactions and the firm whose taxable income increases. The level of tax avoidance by firms belonging to business groups will become higher as the amount of related party transactions increases as the firms conduct a tax strategy using related party transactions. In this regard, the following Hypothesis 1 is set up.

Hypothesis 1. The amount of related party transactions and tax avoidance at firms belonging to a business group are positively associated.

\subsection{Related Party Transactions and Chaebol on Tax Avoidance}

Chaebol is a form of business organization unique to Korea. The economic power of Korea is concentrated on a minority of Chaebol groups. As of 2005, among the firms subject to external audits, the portion of Chaebol is $19.2 \%$ of the total assets and $35.6 \%$ of total sales (Kang 2011 [14]). Chaebol groups control many affiliated firms by circular ownership or internal trading, and the controlling shareholder's family owns and controls Chaebol groups. A Chaebol business group has more and larger affiliated companies than a non-Chaebol business group. Jung et al. (2009) [2] argued that the structure of Chaebol business groups was well-suited to income shifting. A Chaebol business group has a unique corporate governance of a pyramid-type structure or circular ownership, and the controlling shareholder can control the affiliate firms almost perfectly. In such corporate governance, the managerial decisions of affiliate firms are made at the business group level. In particular, Korea does not have an effective monitoring system, and thus, it is possible for the controlling shareholder to make opportunistic decisions. They suggest that Chaebol business groups show lower marginal tax rates than non-Chaebol firms, which implies that Chaebol business groups have lower tax rates by income shifting. Chaebol member firms will set up an aggressive tax strategy using strong financial power. They have various opportunities to minimize tax by related party transactions using various types of affiliate firms with different tax burdens, including those located in overseas countries with low tax rates or those that have net operating loss. In addition, it will be easier for Chaebol member firms to set up the strategy for tax minimization by related party transactions than non-Chaebol firms as their corporate governance is well-suited to tax the minimization strategy at the business group level. Thus, the following Hypothesis 2 is set up.

Hypothesis 2. A firm belonging to a Chaebol business group is more positively associated with the amount of related party transactions and tax avoidance than a firm belonging to a non-Chaebol business group.

\subsection{Related Party Transactions, Chaebol and Unfair Related Party Transactions Tax Law on Tax Avoidance}

Chaebol groups are owned and controlled by the owner families who use unfair related party transactions for tax avoidance and inheritance of wealth for their children. If an affiliated firm owned by a child of the owner of a Chaebol group carries out unfair related party transactions, the value of the firm increases, and the child of the owner of the Chaebol receives a transfer of wealth as much as the increase in the value of the firm. Such a transfer of wealth by unfair related party transactions became a political and social issue, and the Unfair Related Party Transactions Tax Law was introduced at the end of 2011 to regulate such a phenomenon. It is regulated by Article 34-3 of the Inheritance 
and Gift Tax Law (Gift of profits by related party transactions) that a gift tax shall be imposed on the controlling shareholder, etc., of the beneficiary corporation if certain requirements are met for taxation including $30 \%$ or more of the ratio of sales to a related party. Therefore, the related party transactions for tax minimization at the business group level, too, will be done at less than $30 \%$ of the total sales in order to avoid imposition of the gift tax. This will be a constraint on the strategy for tax minimization at the business group level. An effective tax strategy will not be able to be carried out, as not only the transactions for the purpose of the inheritance of wealth, but also related party transactions can be an object of taxation if they exceed a certain percentage. Therefore, it is expected that the Unfair Related Party Transactions Tax Law will affect the tax strategy of using related party transactions at Chaebol groups. Thus, the following Hypothesis 3 is set up.

Hypothesis 3. The positive association of the amount of related party transactions and tax avoidance is weakened in the firms belonging to Chaebol business groups after the implementation of the Unfair Related Party Transactions Tax Law.

\section{Research Design and Sample Selection}

\subsection{Empirical Models}

\subsubsection{Test for the Association between Related Party Transactions and Tax Avoidance (H1)}

The following model (1) has been set up to examine Hypothesis 1, that the amount of related party transactions and tax avoidance are positively associated. Model (1) is the fixed effect model using industry dummy and year dummy.

$$
\begin{aligned}
\text { TAXAVOID }_{i t}= & \beta_{0}+\beta_{1} \text { RPTRAN }_{i t}+\beta_{2} \text { SIZE }_{i t}+\beta_{3} L E V_{i t}+\beta_{4} R O A_{i t}+\beta_{5} C A P_{i t}+\beta_{6} R D_{i t} \\
& +\beta_{7} D A_{i t}+\beta_{8} F S_{i t}+\beta_{9} C S_{i t}+\beta_{10} N O L_{i t}+\beta_{11} M T B_{i t}+\beta_{12-25} I N D_{j} \\
& +\beta_{26-42} Y D_{t}+\epsilon_{i t}
\end{aligned}
$$

where TAXAVOID $=C E T R, D D B T D ; C E T R=($ cash tax paid $/$ adjusted pretax income $) \times(-1) ; D D B T D=$ the measured value of tax avoidance suggested by Desai and Dharmapala (2006) [6]; RPTRAN = related party transactions/total sales; SIZE $=\ln$ (total assets); $L E V=$ debt/lagged total assets; $R O A=$ pretax income/lagged total assets; $C A P=$ tangible assets/lagged total assets; $R D=$ research and development expense/lagged total assets; $D A=$ discretionary accruals estimated by the adjusted Jones model; $F S=$ foreign investor holdings; $C S=$ controlling holdings; $N O L=$ indicator variable equal to one if the firm reported a net operating loss and zero otherwise; $M T B=$ market value of equity/total stockholders' equity.

In Model (1), the dependent variable is the tax avoidance measures, and the interest value is the amount of transactions with related parties. The cash effective tax rate (CETR) and the BTD residual (DDBTD) of Desai and Dharmapala (2006) [6] are used as tax avoidance measures. As the tax avoidance measure is various, it is important to select an appropriate measure by research design. The cash effective tax rate (CETR) is used for the measurement of the overall level of tax burden of firms. The cash effective tax rate (CETR) is the paid corporate tax divided by adjusted pretax income and means the cash tax paid per each unit of pretax income. The interest variable of the amount of transactions with related parties affects the profit and loss of related parties, and the profit and loss of related parties are recognized as gains and losses on equity method accounting and reflected in pretax income. The adjusted pretax income deducting the gains and losses on the equity method accounting from the pretax income is used as the denominator to eliminate the association with the interest variable and the dependent variable. As the amount of the paid tax, which is the numerator of the cash effective tax rate, is paid in cash, it is possible to directly measure the cash outflow due to taxation. For the convenience of interpretation, the variable is defined as having a higher level of tax avoidance if the value of the cash effective tax rate (CETR) multiplied by $(-1)$ is larger. 
The DDBTD of Desai and Dharmapala (2006) [6] is used to capture tax shelter. As managerial discretion is not reflected much for permanent differences in Korea, the tax shelter measure of Frank et al. (2009) [15] using permanent differences is not appropriate. The tax shelter measure suggested by Wilson (2009) [16] is also difficult to use as the existence of the tax shelter suggested by Wilson (2009) [16] is unclear in Korea. Due to such reasons, the DDBTD of Desai and Dharmapala (2006) [6] is used as the tax shelter measure. The estimated model of the BTD residual (DDBTD) of Desai and Dharmapala (2006) [6] is as follows.

$$
B T D_{i t}=\beta_{1} T A_{i t}+\epsilon_{i t}
$$

where $B T D=$ book tax difference $/$ lagged total assets; $T A=$ total accrual/lagged total assets.

The residual $\left(\epsilon_{t}\right)$ from Model (2) is the measure of tax avoidance. The component of book tax difference that cannot be explained with total accrual (earning management) is defined as tax avoidance.

The amount of related party transactions (RPTRAN) is calculated like Lee (2010) [3], Choi et al. (2011) [4] and Kim and Yoo (2017) [17] by dividing the sum of the sales to and purchase from related parties by total sales. If the amount of related party transactions and tax avoidance are positively associated as expected by Hypothesis 1 , the coefficient of RPTRAN $\left(\beta_{1}\right)$ will have a significantly positive value.

Firm size (SIZE), leverage (LEV), return on assets $(R O A)$, the ratio of capital expenditures to total asset $(C A P)$, the ratio of research and development expenses to total asset $(R D)$, discretionary accruals $(D A)$, foreign investors' ownership (FS), controlling shareholder's ownership (CS), dummy variable of net operating loss (NOL) and the market-to-book ratio (MTB) are included in the model to control the factors that had been found to affect tax avoidance in prior research (Graham 1996 [18], Koh et al., 2007 [19], Frank et al., 2009 [15], Desai and Dharmapala 2009 [20], Kang and Kim 2012 [21], Chen et al., 2010 [22], Armstrong et al., 2015 [23]). If the firm size is large, there are sufficient resources that can be used for tax avoidance, but the firm should bear much political cost. As such, firm size affects tax avoidance. As the interest expense for the use of debt is used as a tax shield, the leverage is related to tax avoidance (Graham 1996 [18]). Koh et al., (2007) [19] argued that tax avoidance is done more as the profitability is high to reduce the amount of tax burden, which increases as the profits increase. The acquisition of tangible assets affects cash tax paid through depreciation and investment tax credit, and gains can be deferred and losses realized earlier by adjusting the time of acquisition or disposal of tangible assets. It is possible to avoid tax in various ways using tangible assets. R\&D costs can have a tax credit and also the opportunity for tax avoidance by adjusting the time of recognition of costs through expensing and capitalization. Earnings management is controlled according to Frank et al. (2009) [15], who argue that there is a relationship between accrual earnings management and tax avoidance. Analyzing the agency-view of tax avoidance, this study suggests corporate governance as the major determinants of tax avoidance (Desai and Dharmapala 2009 [20], Kang and Kim 2012 [21], Chen et al., 2010 [22], Armstrong et al., 2015 [23]). Accordingly, foreign investors' ownership (FS) and controlling shareholder's ownership (CS) are included in the model. A company that has a net operating loss cannot use the benefits of tax deduction, tax credit or tax reduction more effectively than a company that does not have net operating loss. However, a company that has net operating loss has less tax as its profitability is low and the net operating loss can be deducted from taxable income. Net operating loss is related to tax avoidance. The market to book ratio (MTB) means a growth opportunity for a company. A growth firm can reduce its tax rate by investing in tax benefit assets that can adjust the time of recognition of costs (Chen et al., 2010 [22]). Furthermore, the year dummy (YD) is used to control the changes in tax environment such as the change in tax rate during the sample period and the industry dummy (IND) to control industry effects.

\subsubsection{Test for the Effect of Related Party Transactions and Chaebol on Tax Avoidance (H2)}

The following model (3) is set up to examine Hypothesis 2 that Chaebol member firms have a more positive association of the amount of related party transactions and tax avoidance than non-Chaebol firms. Model (3) is the fixed effect model using the industry dummy and year dummy. 


$$
\begin{aligned}
\text { TAXAVOID }_{i t}= & \beta_{0}+\beta_{1} R P T R A N_{i t}+\beta_{2} R_{P T R A N} \times C B_{i t}+\beta_{3} C B_{i t}+\beta_{4} S I Z E_{i t}+\beta_{5} L E V_{i t} \\
& +\beta_{6} R O A_{i t}+\beta_{7} C A P_{i t}+\beta_{8} R D_{i t}+\beta_{9} D A_{i t}+\beta_{10} F S_{i t}+\beta_{11} C S_{i t}+\beta_{12} N O L_{i t} \\
& +\beta_{13} M T B_{i t}+\beta_{14-27} I N D_{j}+\beta_{28-44} Y D_{t}+\epsilon_{i t}
\end{aligned}
$$

where $C B$ indicator variable equal to one if the firm is a Chaebol member firm and zero otherwise.

A main explanation variable in Model (3) is RPTRAN $\times C B$, which is an interaction term of the amount of related party transactions and the dummy variable of Chaebol business groups. $\beta_{2}$ is expected to be a significant positive value if the positive association of the amount of related party transactions and tax avoidance in a Chaebol member firm increases as expected in Hypothesis 2.

3.1.3. Test for the Effect of Related Party Transactions, Chaebol and Unfair Related Party Transactions Tax Law on Tax Avoidance (H3)

The following model (4) is set up to examine Hypothesis 3 that the positive association of the amount of related party transactions and tax avoidance is weakened in Chaebol member firms after the implementation of the Unfair Related Party Transactions Tax Law. Model (4) is the fixed effect model using the industry dummy and year dummy.

$$
\begin{aligned}
\text { TAXAVOID }_{i t}= & \beta_{0}+\beta_{1} \operatorname{RPTRAN}_{i t}+\beta_{2} R P T R A N_{i t} \times C B_{i t}+\beta_{3} R_{P T R A N} \times C B_{i t} \times E V E N T_{i t} \\
& +\beta_{4} R P T R A N_{i t} \times E V E N T_{i t}+\beta_{5} C B_{i t}+\beta_{6} E V E N T_{i t}+\beta_{7} S I Z E_{i t}+\beta_{8} L E V_{i t} \\
& +\beta_{9} R O A_{i t}+\beta_{10} C A P_{i t}+\beta_{11} R D_{i t}+\beta_{12} D A_{i t}+\beta_{13} F S_{i t}+\beta_{14} C S_{i t}+\beta_{15} N O L_{i t} \\
& +\beta_{16} M T B_{i t}+\beta_{17-30} I N D_{j}+\epsilon_{i t}
\end{aligned}
$$

where EVENT = indicator variable equal to zero if the time is after 2012 when the Unfair Related Party Transactions Tax Law took effect and one otherwise.

A main explanation variable in Model (4) is RPTRAN $\times C B \times E V E N T$, which is an interaction term of the amount of related party transactions and the dummy variable of the Chaebol business group and the dummy variable of the period before the implementation of the Unfair Related Party Transactions Tax Law. For the convenience of interpretation, EVENT is defined as zero for the period after the implementation of the Unfair Related Party Transactions Tax Law and one for the period before the implementation of the law. $\beta_{3}$ will have a significant positive value if the positive association of the amount of related party transactions and tax avoidance is weakened in Chaebol member firms after the implementation of the Unfair Related Party Transactions Tax Law, as expected in Hypothesis 3.

\subsection{Samples and Data}

The initial sample is composed of publicly-traded firms in the KOSPI (Korea Composite Stock Price Index) market. The KOSPI market is the largest listed market in Korea, which is similar to the NYSE (New York Stock Exchange) market in the U.S. We set the test period to run from 2001-2016. We also require that the sample firms have a December year-end and operate in non-financial industries in order to minimize noise from inconsistent fiscal year and accounting practices. The firms that recorded negative cash tax paid and adjusted pretax income are excluded because the reliability of the measured value cannot be secured if the denominator or numerator of the cash effective tax rate has a negative value. In addition, the cash effective tax rate exceeding one is regarded as an outlier and adjusted to one. Article 2 of the Monopoly Regulation and Fair Trade Act defines the term "business group": where the controlling shareholder is a company, a business group comprised of such controlling shareholder and one or more companies controlled by that controlling shareholder; and where the controlling shareholder is not a company, a business group comprised of two or more companies controlled by that controlling shareholder. According to such a definition, a firm with less than one related party is excluded in this sample regarding that the firm is not a business group. 
The accounting data were obtained from the TS-2000 database and the stock return data from Dataguide Pro of FNGuide. The data of cash tax paid is collected using the footnote of the audit report. We winsorize all the continuous variables at the $1 \%$ and $99 \%$ levels to mitigate the effect from extreme outliers. Next, sample observations with missing values for the test variables are rejected. Finally, the number of samples used for the empirical analysis is 5738 firm-years by cash effective tax rate and 7322 firm-years by DDBTD.

\section{Empirical Results}

\subsection{Descriptive Statistics and Correlations}

Table 1 provides the descriptive statistics of variables for the main analysis. The mean of cash effective tax rate (CETR) was -0.219 , which implies that firms paid $21.9 \%$ of pretax income for corporate tax. The mean of BTD residual (DDBTD) was 0.008 . The mean of the amount of related party transactions (RPTRAN) was 0.260 , which implies that the firms in business groups did related party transactions by $26 \%$ of their sales on average. The median of amount of related party transactions was 0.149 , and the mean value was 0.260 , which implies that some firms did large-scale related party transactions. The mean of the dummy variable of belonging to Chaebol business groups $(C B)$ was 0.274 , which implies that $27.4 \%$ of the firms in business groups were Chaebol member firms. The mean of dummy variable for the introduction of the Unfair Related Party Transactions Tax Law (EVENT) was 0.624 , which implies that $62.4 \%$ of the samples belonged to the period before the implementation of the Unfair Related Party Transactions Tax Law. The mean of firm size (SIZE) was 19.795, and the mean of debt ratio $(L E V)$ was 0.434 . Thus, it was shown that firms had debt level of $43.4 \%$ of their total assets on average. The mean of profitability $(R O A)$ was 0.043 , which implies that the firms in business groups were turning a profit on average. The mean of tangible asset $(C A P)$ was 0.331 , and the mean of R\&D expense $(R D)$ was 0.013 . The mean of discretionary accruals $(D A)$ was -0.002 , which is almost zero. Foreign investors' ownership (FS) was 0.104 , which implies that foreigners had $10.4 \%$ of shares. The mean of controlling shareholder's ownership (CS) was 0.428 , showing the considerable share of the controlling shareholder. The dummy variable for net operating loss (NOL) was 0.150 , which implies that $15 \%$ of the firms in business groups had net operating loss. The mean of MTB was 1.153, which implies that the market value was more than the book value. Considering that the median value was 0.810 , it was show that some firms had much more market value than their book value.

Table 1. Descriptive statistics.

\begin{tabular}{ccccccccc}
\hline Variable & $\mathbf{N}$ & Mean & Std. & Min & $\mathbf{2 5 \%}$ & Median & $\mathbf{7 5 \%}$ & Max \\
\hline CETR & 5738 & -0.219 & 0.172 & -1.000 & -0.300 & -0.221 & -0.090 & 0.000 \\
DDBTD & 7322 & 0.008 & 0.064 & -0.232 & -0.022 & 0.010 & 0.039 & 0.288 \\
RPTRAN & 7322 & 0.260 & 0.297 & 0.000 & 0.033 & 0.149 & 0.380 & 1.274 \\
CB & 7322 & 0.274 & 0.446 & 0.000 & 0.000 & 0.000 & 1.000 & 1.000 \\
EVENT & 7322 & 0.624 & 0.484 & 0.000 & 0.000 & 1.000 & 1.000 & 1.000 \\
SIZE & 7322 & 19.795 & 1.501 & 16.917 & 18.750 & 19.523 & 20.616 & 23.998 \\
LEV & 7322 & 0.434 & 0.200 & 0.032 & 0.279 & 0.442 & 0.581 & 0.923 \\
ROA & 7322 & 0.043 & 0.088 & -0.309 & 0.009 & 0.043 & 0.089 & 0.288 \\
CAP & 7322 & 0.331 & 0.204 & 0.000 & 0.187 & 0.327 & 0.457 & 3.023 \\
RD & 7322 & 0.013 & 0.030 & 0.000 & 0.000 & 0.004 & 0.017 & 1.697 \\
DA & 7322 & -0.002 & 0.073 & -0.250 & -0.037 & -0.001 & 0.036 & 0.249 \\
FS & 7322 & 0.104 & 0.139 & 0.000 & 0.007 & 0.040 & 0.150 & 0.614 \\
CS & 7322 & 0.428 & 0.163 & 0.077 & 0.311 & 0.427 & 0.534 & 0.818 \\
NOL & 7322 & 0.150 & 0.357 & 0.000 & 0.000 & 0.000 & 0.000 & 1.000 \\
MTB & 7322 & 1.153 & 1.110 & 0.151 & 0.500 & 0.810 & 1.354 & 7.161 \\
\hline
\end{tabular}

Refer to Equations (1)-(4) for the definitions of the variables.

Table 2 summarizes the Pearson correlations among the main test variables. The tax avoidance measures of CETR and DDBTD had significant positive association. If the effective tax rate was low, the BTD residual increased. RPTRAN and EVENT were positively correlated with tax avoidance 
measures (CETR, DDBTD). Thus, the level of tax avoidance was higher as the amount of related party transactions was larger and the period was before the implementation of the Unfair Related Party Transactions Tax Law. CB was negatively associated with CETR and positively associated with DDBTD, showing a difference by the measures of tax avoidance. While the firms in Chaebol business groups had a great burden of corporate tax in comparison to pretax income, their DDBTD was large. This implied that Chaebol groups had a high level of burden of corporate tax due to much political cost, and they often used a tax shelter for their conducted tax strategy. RPTRAN was positively correlated with $C B$ and EVENT. Chaebol groups did more related party transactions, and related party transactions were more active before the implementation of the Unfair Related Party Transactions Tax Law than after the implementation of the law. EVENT and $C B$ were in negative association, and there were fewer companies that belonged to $C B$ before 2012. A business groups was designated as a Chaebol business group if its aggregate market price became more than KRW five trillion. The number of business groups that had been designated as Chaebol increased from 30 in 2001 to 62 in 2016 with the increased aggregate market prices of listed firms. As a result, more firms were classified as Chaebol after 2012.

The VIF (Variance Inflation Factor) was examined to see the existence of multicollinearity among explanatory variables, and it was confirmed that there is no problem of multicollinearity.

Table 2. Correlations among the variables.

\begin{tabular}{|c|c|c|c|c|c|c|c|}
\hline & CETR & DDBTD & RPTRAN & $C B$ & EVENT & $S I Z E$ & $L E V$ \\
\hline DDBTD & 0.280 & & & & & & \\
\hline RPTRAN & 0.051 & 0.026 & & & & & \\
\hline$C B$ & -0.043 & 0.087 & 0.109 & & & & \\
\hline EVENT & 0.000 & 0.107 & 0.025 & -0.048 & & & \\
\hline SIZE & -0.079 & 0.148 & 0.068 & 0.644 & -0.124 & & \\
\hline$L E V$ & -0.008 & -0.094 & -0.119 & 0.179 & 0.093 & 0.166 & \\
\hline$R O A$ & 0.027 & 0.502 & -0.012 & 0.041 & 0.119 & 0.157 & -0.322 \\
\hline$C A P$ & 0.034 & 0.181 & -0.155 & 0.045 & 0.152 & 0.123 & 0.207 \\
\hline$R D$ & -0.012 & 0.004 & 0.027 & -0.030 & 0.026 & 0.021 & -0.017 \\
\hline$D A$ & 0.042 & -0.002 & 0.008 & -0.028 & 0.023 & 0.004 & -0.118 \\
\hline$F S$ & -0.095 & 0.118 & 0.055 & 0.284 & 0.006 & 0.507 & -0.121 \\
\hline$C S$ & 0.007 & 0.052 & 0.066 & -0.035 & -0.071 & -0.071 & -0.142 \\
\hline NOL & 0.160 & -0.299 & -0.007 & -0.031 & -0.012 & -0.155 & 0.290 \\
\hline \multirow[t]{2}{*}{ MTB } & 0.044 & -0.024 & 0.033 & 0.104 & -0.128 & 0.085 & 0.100 \\
\hline & $R O A$ & $C A P$ & $R D$ & $D A$ & FS & $C S$ & NOL \\
\hline$C A P$ & 0.048 & & & & & & \\
\hline$R D$ & 0.054 & -0.023 & & & & & \\
\hline$D A$ & 0.391 & 0.011 & -0.007 & & & & \\
\hline$F S$ & 0.286 & 0.017 & 0.119 & -0.008 & & & \\
\hline$C S$ & 0.122 & 0.033 & -0.104 & 0.093 & -0.177 & & \\
\hline$N O L$ & -0.532 & -0.014 & 0.027 & -0.212 & -0.161 & -0.173 & \\
\hline MTB & 0.094 & -0.095 & 0.195 & -0.078 & 0.220 & -0.148 & 0.114 \\
\hline
\end{tabular}

(1) Refer to Equations (1)-(4) for the definitions of the variables; (2) this table presents Pearson correlations. Coefficients shown in bold are significant at $p<0.05$ (two-tailed test).

\subsection{Regression Results}

\subsubsection{Results for the Effect of Related Party Transactions on Tax Avoidance (H1)}

Table 3 presents the test results for the effect of Related Party Transactions on Tax Avoidance, which we analyzed in Hypotheses 1. The first column reports the result using CETR as the dependent variable, and the second column reports the result using $D D B T D$ as the dependent variable. According to the results of the analysis, the coefficient of RPTRAN $\left(\beta_{1}\right)$ was 0.017 when CETR was used as the measure of tax avoidance, and it was significant at the $5 \%$ level. The coefficient of RPTRAN was 0.011 when DDBTD was used as the measure of tax avoidance, and it was significant at $1 \%$ level. While the adjusted R-squared had a value of 0.354 in the model that used DDBTD as the measure of tax 
avoidance, the model that used CETR as the measure of tax avoidance had a rather low value of 0.069 . Chen (2010) [22] and Edwards et al. (2015) [24], which used CETR as the dependent variable, as well, reported $0.052-0.125$ of adjusted $R$-squared having an explanation power similar to prior research. Such results support Hypothesis 1 of this study that the amount of related party transactions and tax avoidance are positively associated. It suggests that if tax were minimized at the business group level by related party transactions, the level of tax avoidance at the individual firm level would also be high. It was shown that the firms in business groups avoided tax using related party transactions.

The endogeneity test was done with Hausman's specification test, as tax avoidance, also, can affect related party transaction amount. The industrial mean of related party transaction amount was used as the instrumental variable. The results of analysis show that there was no endogeneity. It has also been examined with the Durbin-Watson test to see if there was autocorrelation in the error term. There was no autocorrelation, as the Durbin-Watson D-value was near two and the first order autocorrelation was near zero.

Table 3. The effect of related party transactions on tax avoidance.

\begin{tabular}{|c|c|c|c|c|c|c|}
\hline \multirow{3}{*}{$\begin{array}{c}\text { Variables } \\
\text { Intercept }\end{array}$} & \multicolumn{3}{|c|}{ (1) Dependent $=$ CETR } & \multicolumn{3}{|c|}{ (2) Dependent $=D D B T D$} \\
\hline & \multirow{2}{*}{$\begin{array}{l}\text { Estimate } \\
-0.165\end{array}$} & \multicolumn{2}{|c|}{$p$-Value } & \multirow{2}{*}{$\begin{array}{l}\text { Estimate } \\
-0.075\end{array}$} & \multicolumn{2}{|c|}{$p$-Value } \\
\hline & & $<0.0001$ & $* * *$ & & $<0.0001$ & $* * *$ \\
\hline RPTRAN & 0.017 & 0.039 & $* *$ & 0.011 & $<0.0001$ & $* * *$ \\
\hline SIZE & -0.005 & 0.010 & $* * *$ & 0.003 & $<0.0001$ & $* * *$ \\
\hline$L E V$ & 0.001 & 0.958 & & 0.017 & $<0.0001$ & $* * *$ \\
\hline$R O A$ & 0.153 & 0.001 & $* * *$ & 0.451 & $<0.0001$ & $* * *$ \\
\hline$C A P$ & 0.031 & 0.013 & $* *$ & 0.042 & $<0.0001$ & $* * *$ \\
\hline$R D$ & -0.125 & 0.268 & & -0.010 & 0.664 & \\
\hline$D A$ & 0.041 & 0.231 & & -0.224 & $<0.0001$ & $* * *$ \\
\hline FS & -0.092 & $<0.0001$ & $* * *$ & -0.042 & $<0.0001$ & $* * *$ \\
\hline$C S$ & -0.014 & 0.348 & & -0.008 & 0.035 & $* *$ \\
\hline NOL & 0.139 & $<0.0001$ & $* * *$ & -0.006 & 0.002 & $* * *$ \\
\hline MTB & 0.007 & 0.004 & $* * *$ & -0.005 & $<0.0001$ & $* * *$ \\
\hline Fixed Effect & \multicolumn{3}{|c|}{ Industry and Year } & \multicolumn{3}{|c|}{ Industry and Year } \\
\hline Adj. R2 & \multicolumn{3}{|c|}{0.069} & \multicolumn{3}{|c|}{0.354} \\
\hline $\mathrm{N}$ (Observations) & \multicolumn{3}{|c|}{5738} & \multicolumn{3}{|c|}{7322} \\
\hline
\end{tabular}

(1) Refer to Equations (1)-(4) for the definitions of the variables; $(2)^{*}, * *, * * *$ indicate significance at the 10 percent, 5 percent and 1 percent levels, respectively.

\subsubsection{Results for the Effect of Related Party Transactions and Chaebol on Tax Avoidance (H2)}

Table 4 presents the test results for the effect of Related Party Transactions and Chaebol on tax avoidance, which we analyze in Hypotheses 2 . The first column reports the result using CETR as the dependent variable, and the second column reports the result using $D D B T D$ as the dependent variable. Here, the coefficient of $R P T R A N\left(\beta_{1}\right)$ represents the relationship between the related party transaction amount of non-Chaebol firms and tax avoidance, and the coefficient of $R P T R A N \times C B\left(\beta_{2}\right)$ is the difference between the effect of the related party transactions of non-Chaebol firms on tax avoidance and the effect of the related party transactions of Chaebol member firms on tax avoidance. It is possible to know the effect of the related party transaction amount of Chaebol member firms on tax avoidance by adding $\beta_{1}$ and $\beta_{2}$. According to the results of the analysis, the coefficient of RPTRAN $\times C B$ was 0.034 when $C E T R$ was used as the measure of tax avoidance, and it was significant at the $5 \%$ level. The coefficient of RPTRAN was 0.008 when DDBTD was used as the measure of tax avoidance, and it was significant at the $10 \%$ level. This is interpreted as the effect of the related party transaction amount 
of Chaebol member firms on tax avoidance being greater than the effect of the related party transaction amount of non-Chaebol firms on tax avoidance. Such results support Hypothesis 2 of this research that a Chaebol member firm is more positively associated with the amount of related party transactions and tax avoidance than a non-Chaebol firm. It seems that Chaebol member firms can do tax avoidance more easily by related party transactions than non-Chaebol firms using various kinds of affiliated firms and sufficient financial power. This result corresponds with the argument of Jung et al. (2009) [2].

Table 4. The effect of related party transactions and Chaebol on tax avoidance.

\begin{tabular}{|c|c|c|c|c|c|c|}
\hline \multirow{3}{*}{$\begin{array}{l}\text { Variables } \\
\text { Intercept }\end{array}$} & \multicolumn{3}{|c|}{ (1) Dependent $=C E T R$} & \multicolumn{3}{|c|}{ (2) Dependent $=D D B T D$} \\
\hline & \multirow{2}{*}{$\begin{array}{l}\text { Estimate } \\
-0.121\end{array}$} & \multicolumn{2}{|c|}{$p$-Value } & \multirow{2}{*}{$\begin{array}{c}\text { Estimate } \\
-0.056\end{array}$} & \multicolumn{2}{|c|}{$p$-Value } \\
\hline & & 0.011 & $* *$ & & $<0.0001$ & $* * *$ \\
\hline RPTRAN & 0.003 & 0.726 & & 0.008 & 0.002 & $* * *$ \\
\hline$R P T R A N \times C B$ & 0.034 & 0.035 & $* *$ & 0.008 & 0.075 & $*$ \\
\hline$C B$ & 0.000 & 0.975 & & 0.002 & 0.282 & \\
\hline SIZE & -0.007 & 0.002 & $* * *$ & 0.002 & 0.005 & $* * *$ \\
\hline$L E V$ & -0.001 & 0.951 & & 0.016 & $<0.0001$ & $* * *$ \\
\hline$R O A$ & 0.152 & 0.001 & $* * *$ & 0.451 & $<0.0001$ & $* * *$ \\
\hline$C A P$ & 0.032 & 0.012 & $* *$ & 0.042 & $<0.0001$ & $* * *$ \\
\hline$R D$ & -0.135 & 0.234 & & -0.009 & 0.670 & \\
\hline$D A$ & 0.043 & 0.212 & & -0.224 & $<0.0001$ & $* * *$ \\
\hline FS & -0.091 & $<0.0001$ & $* * *$ & -0.042 & $<0.0001$ & $* * *$ \\
\hline$C S$ & -0.013 & 0.386 & & -0.008 & 0.036 & $* *$ \\
\hline NOL & 0.139 & $<0.0001$ & $* * *$ & -0.007 & 0.002 & $* * *$ \\
\hline MTB & 0.007 & 0.004 & $* * *$ & -0.005 & $<0.0001$ & $* * *$ \\
\hline Fixed Effect & \multicolumn{3}{|c|}{ Industry and Year } & \multicolumn{3}{|c|}{ Industry and Year } \\
\hline Adj. R2 & \multicolumn{3}{|c|}{0.070} & \multicolumn{3}{|c|}{0.355} \\
\hline N (Observations) & \multicolumn{3}{|c|}{5738} & \multicolumn{3}{|c|}{7322} \\
\hline
\end{tabular}

(1) Refer to equations (1)-(4) for the definitions of the variables; $(2)^{*}, * *, * * *$ indicate significance at the 10 percent, 5 percent and 1 percent levels, respectively.

4.2.3. Results for the Effect of Related Party Transactions, Chaebol and Unfair Related Party Transactions Tax Law on Tax Avoidance (H3)

Table 4 presents the test results for the effect of Related Party Transactions, Chaebol and unfair related party transactions tax law on tax avoidance, which we analyze in Hypotheses 3 . The first column reports the result using CETR as the dependent variable, and the second column reports the result using DDBTD as the dependent variable. Here, the coefficient of RPTRAN $\times C B \times E V E N T\left(\beta_{3}\right)$ represents it there is a difference before and after the implementation of the Unfair Related Party Transactions Tax Law between the effect of the related party transactions of non-Chaebol firms on tax avoidance and the effect of the related party transactions of Chaebol member firms on tax avoidance. The coefficient of RPTRAN ( $\left.\beta_{1}\right)$ represents the effect of non-Chaebol firms after the implementation of the Unfair Related Party Transactions Tax Law, and the coefficient of $R P T R A N \times C B\left(\beta_{2}\right)$ represents the difference between non-Chaebol firms and Chaebol member firms after the implementation of the Unfair Related Party Transactions Tax Law. The coefficient of RPTRAN $\times$ EVENT $\left(\beta_{4}\right)$ represents the difference in non-Chaebol firms between before and after the implementation of the Unfair Related Party Transactions Tax Law. It is possible to know the relationship between the related party transactions and tax avoidance in Chaebol member firms before the implementation of the Unfair Related Party Transactions Tax Law by adding $\beta_{1}, \beta_{2}, \beta_{3}$ and $\beta_{4}$. According to the results of the 
analysis, the coefficient of RPTRAN $\times C B \times E V E N T$ was 0.108 when CETR was used as the measure of tax avoidance, and it was significant at the $1 \%$ level. The coefficient of RPTRAN was 0.021 when $D D B T D$ was used as the measure of tax avoidance, and it was significant at the $5 \%$ level. It was interpreted that the difference between the effect of related party transactions of non-Chaebol firms on tax avoidance and the effect of related party transactions of Chaebol member firms on tax avoidance was greater before the implementation of the Unfair Related Party Transactions Tax Law than after the implementation of the law. Such results support Hypothesis 3 of this research that the positive association of the amount of related party transactions and tax avoidance is weakened in Chaebol member firms after the implementation of the Unfair Related Party Transactions Tax Law. It suggests that regulation of the percentage of related party transactions by the implementation of the Unfair Related Party Transactions Tax Law works as a constraint on the tax strategy using related party transactions. It seems that Chaebol business groups, which avoid tax by related party transactions more often, are affected more by the measures. It is shown that the Unfair Related Party Transactions Tax Law reduced not only the unfair inheritance of wealth, but also the tax avoidance of Chaebol business groups conducted by internal transactions. See Table 5 .

Table 5. The effect of related party transactions, Chaebol and unfair related party transactions tax law on tax avoidance.

\begin{tabular}{|c|c|c|c|c|c|c|}
\hline \multirow{3}{*}{$\begin{array}{l}\text { Variables } \\
\text { Intercept }\end{array}$} & \multicolumn{3}{|c|}{ (1) Dependent $=C E T R$} & \multicolumn{3}{|c|}{ (2) Dependent $=D D B T D$} \\
\hline & \multirow{2}{*}{$\begin{array}{c}\text { Estimate } \\
-0.158\end{array}$} & \multicolumn{2}{|c|}{$p$-Value } & \multirow{2}{*}{$\begin{array}{c}\text { Estimate } \\
-0.055\end{array}$} & \multicolumn{2}{|c|}{$p$-Value } \\
\hline & & 0.001 & $* * *$ & & $<0.0001$ & $* * *$ \\
\hline RPTRAN & 0.041 & 0.004 & $* * *$ & 0.012 & 0.002 & $* * *$ \\
\hline$R P T R A N \times C B$ & -0.008 & 0.697 & & -0.001 & 0.850 & \\
\hline $\begin{array}{c}\text { RPTRAN } \times C B \times \\
\text { EVENT }\end{array}$ & 0.072 & 0.003 & $* * *$ & 0.015 & 0.026 & $* *$ \\
\hline$R P T R A N \times E V E N T$ & -0.063 & 0.000 & $* * *$ & -0.007 & 0.158 & \\
\hline$C B$ & -0.003 & 0.727 & & 0.003 & 0.241 & \\
\hline EVENT & 0.004 & 0.503 & & 0.001 & 0.514 & \\
\hline SIZE & -0.005 & 0.025 & $* *$ & 0.002 & 0.007 & $* * *$ \\
\hline LEV & -0.004 & 0.765 & & 0.016 & $<0.0001$ & $* * *$ \\
\hline$R O A$ & 0.159 & 0.000 & $* * *$ & 0.451 & $<0.0001$ & $* * *$ \\
\hline$C A P$ & 0.030 & 0.019 & $* *$ & 0.042 & $<0.0001$ & $* * *$ \\
\hline$R D$ & -0.135 & 0.234 & & -0.013 & 0.554 & \\
\hline$D A$ & 0.043 & 0.216 & & -0.223 & $<0.0001$ & $* * *$ \\
\hline$F S$ & -0.103 & $<0.0001$ & $* * *$ & -0.042 & $<0.0001$ & $* * *$ \\
\hline$C S$ & -0.010 & 0.498 & & -0.009 & 0.024 & $* *$ \\
\hline NOL & 0.140 & $<0.0001$ & $* * *$ & -0.007 & 0.001 & $* * *$ \\
\hline MTB & 0.007 & 0.006 & $* * *$ & -0.005 & $<0.0001$ & $* * *$ \\
\hline Fixed Effect & \multicolumn{3}{|c|}{ Industry } & \multicolumn{3}{|c|}{ Industry } \\
\hline Adj.R2 & \multicolumn{3}{|c|}{0.063} & \multicolumn{3}{|c|}{0.353} \\
\hline N(Observations) & \multicolumn{3}{|c|}{5738} & \multicolumn{3}{|c|}{7322} \\
\hline
\end{tabular}

(1) Refer to Equations (1)-(4) for the definitions of the variables; $(2)^{*}, * *, * * *$ indicate significance at the 10 percent, 5 percent and 1 percent levels, respectively.

\section{Conclusions}

Firms have an incentive to minimize corporate tax, which is an important item of cash outflow. Firms in a business group perform the strategy for tax minimization at the business group level using 
related party transactions. This study has examined the effect of related party transactions of the firms in business groups on the tax avoidance at the individual firm level and also examined if Chaebol member firms have stronger association. It is expected that Chaebol business groups can do tax avoidance more easily as they have a corporate governance well-suited to income shifting by related party transactions and various affiliate firms with different levels of tax burden. Furthermore, it is expected that the tax avoidance of Chaebol business groups by related party transactions will decrease after the implementation of the Unfair Related Party Transactions Tax Law, which went into effect in late 2011, as the law imposes tax for transactions between related parties that exceed $30 \%$ of the total sales.

The results of the analysis show, first, that the level of tax avoidance was higher when the amount of related party transactions became larger. Second, the positive association of the amount of related party transactions and tax avoidance was stronger in Chaebol member firms. Third, the positive association of the amount of related party transactions and tax avoidance was weakened in Chaebol member firms after the implementation of the Unfair Related Party Transactions Tax Law. Such results show that the firms in business groups in Korea use related party transactions as a method to do tax avoidance, and such a phenomenon occurs more often among Chaebol business groups. In addition, it is shown that the Unfair Related Party Transactions Tax Law restrains tax avoidance by related party transactions at Chaebol member firms.

This study is meaningful in that it has shown that the tax minimization strategy at the business group level by related party transactions is also related to the tax avoidance at the individual firm level. It has also shown the necessity for the expansion of the system of consolidated tax return, as unnecessary related party transactions for tax avoidance will decrease if the difference in tax burden among the firms in the business group is lessened. In addition, this study provides evidence for the effect of the Unfair Related Party Transactions Tax Law on restraining tax avoidance, though it was originally introduced for the prevention of unfair inheritance of wealth using related party transactions.

Author Contributions: All of contents in this paper were written by author including the review of prior studies, data analysis and models design.

Conflicts of Interest: The author declares no conflict of interest.

\section{References}

1. Gramlich, J.D.; Limpaphayomb, P.; Rhee, S.G. Taxes, Keiretsu affiliation, and income shifting. J. Account. Econ. 2004, 37, 203-228. [CrossRef]

2. Jung, K.Y.; Kim, B.Y.; Kim, B.M. Tax motivated income shifting and Korean business groups (Chaebol). J. Bus. Financ. Account. 2009, 36, 552-586. [CrossRef]

3. Lee, D. The effect of controlling company's tax burden on income shifting through intra-transaction. Korean Account. Rev. 2010, 35, 147-182.

4. Choi, W.; Koh, Y.; Cho, J. Related party transactions and tax avoidance. Korean J. Tax. Res. 2011, 28, 9-35.

5. Lee, S.; Yoon, S. Income shifting using internal trading within business group. Korean J. Tax. Res. 2012, 29, 121-156.

6. Desai, M.; Dharmapala, D. Corporate tax avoidance and high powered incentives. J. Financ. Econ. 2006, 79, 145-179. [CrossRef]

7. Kim, H. An Analysis of the Effect of the Consolidated Tax Return System Introduced on a Corporate Type by Corporate Type Basis. Master's Thesis, University of Seoul, Seoul, Korea, 2015.

8. Harris, D.; Morck, R.; Slemrod, J.; Yeung, B. Income shifiting in W.S. multinational corporateions. In Studies in International Taxaton; Giovannini, A., Huhhard, R., Slemrod, J., Eds.; University of Chicago Press: Chicago, IL, USA, 1993; pp. 277-308.

9. Klassen, K.; Lang, M.; Wolfson, M. Geographic income shifting by multinational corporations in response to tax rate changes. J. Account. Res. 1993, 31, 141-173. [CrossRef]

10. Jacob, J. Taxes and transfer pricing: Income shifting and the volume of intrafirm transfers. J. Account. Res. 1996, 34, 301-312. [CrossRef] 
11. Collins, J.; Kemsley, D.; Lang, M. Cross jurisdictional income shifting and earnings valuation. J. Account. Res. 1998, 3, 209-229. [CrossRef]

12. Ko, J.K. Transfer pricing and tax minimization: Income shifting by Korea multinational companies. Korean Account. Rev. 2000, 25, 51-77.

13. Shackelford, D.; Shevlin, T. Empirical tax research in accounting. J. Account. Econ. 2001, 31, 321-387. [CrossRef]

14. Kang, S. Issues and Policy Improvements of Korean conglomerates regulation. Daehan J. Bus. 2011, 24, 507-532.

15. Frank, M.; Lynch, L.; Rego, S. Tax reporting aggressiveness and its relation to aggressive financial reporting. Account. Rev. 2009, 84, 467-496. [CrossRef]

16. Wilson, R. An examination of corporate tax shelter participants. Account. Rev. 2009, 84, 969-999. [CrossRef]

17. Kim, S.; Yoo, J. Does R\&D Expenditure with Heavy Related Party Transactions Harm Firm Value? Sustain. J. 2017, 9, 1216. [CrossRef]

18. Graham, J. Proxies for the corporate marginal tax rate. J. Financ. Econ. 1996, 42, 187-221. [CrossRef]

19. Koh, Y.S.; Kim, J.H.; Choi, W.W. A study on corporate tax avoidance. Korean J. Tax. Res. 2007, $24,9-40$.

20. Desai, M.; Dharmapala, D. Corporate tax avoidance and firm value. Rev. Econ. Stat. 2009, 91, 537-546. [CrossRef]

21. Kang, J.Y.; Kim, Y.C. Corporate tax avoidance and ownership structure. Korean J. Tax. Res. 2012, $29,37-67$.

22. Chen, S.; Chen, X.; Cheng, Q.; Shevlin, T.J. Are family firms more tax aggressive than non-family firms? J. Financ. Econ. 2010, 95, 41-61. [CrossRef]

23. Armstrong, C.; Blouin, J.; Jagolinzer, A.; Larcker, D. Corporate governance, incentives, and tax avoidance. J. Account. Econ. 2015, 60, 1-17. [CrossRef]

24. Edwards, A.; Schwab, C.; Shevlin, T. Financial Constraints and Cash Tax Savings; Working Paper; University of Toronto: Toronto, ON, Canada; University of Georgia: Athens, GA, USA; University of California at Irvine: Irvine, CA, USA, 2015. [CrossRef]

(C) 2018 by the author. Licensee MDPI, Basel, Switzerland. This article is an open access article distributed under the terms and conditions of the Creative Commons Attribution (CC BY) license (http:/ / creativecommons.org/licenses/by/4.0/). 